\title{
Circulating Activated T Lymphocyte Subsets in Patients with Silent Thyroiditis
}

\author{
KenjI KUSHIMA, Yoshio BAN, Matsuo TANIYAMA, \\ AND KUNIHIKO ITOH* \\ The 3 rd Department of Internal Medicine, Showa University School of Medicine, \\ Tokyo 142, and *Ito Hospital, Tokyo 150, Japan
}

\begin{abstract}
In order to investigate the immunological aspects of silent thyroiditis, T lymphocyte subsets were analyzed by two-color flow cytometry in 10 patients with silent thyroiditis in the thyrotoxic phase, 12 patients with silent thyroiditis in the recovery phase, and 11 healthy volunteers as a control. The percentages of $\mathrm{CD}^{+}, \mathrm{CD}^{+}$, and $\mathrm{CD}^{+}$cells were similar in all three groups. In contrast, activated matured $\mathrm{T}\left(\mathrm{HLA}-\mathrm{DR}^{+} \mathrm{CD} 3^{+}\right)$, activated helper/inducer $\mathrm{T}\left(\mathrm{HLA}-\mathrm{DR}{ }^{+} \mathrm{CD}^{+}\right)$and activated suppressor/ cytotoxic $\mathrm{T}\left(\mathrm{HLA}-\mathrm{DR}{ }^{+} \mathrm{CD}^{+}\right)$cells were more numerous in both the thyrotoxic and the recovery phases of patients with silent thyroiditis when compared with healthy controls. In a serial study of 6 patients with silent thyroiditis, the percentage of activated helper/inducer T (HLA-DR+ ${ }^{+} \mathrm{CD}^{+}$) cells was higher in the thyrotoxic phase than in the recovery phase. These data indicate that the activation of $\mathrm{T}$ cells, especially of helper/inducer T cells, might be important for the induction of silent thyroiditis.
\end{abstract}

Key words: Silent thyroiditis, T cell subsets, Monoclonal antibody, Flow cytometry, Two-color dye labeling

(Endocrine Journal 41: 663-669, 1994)

SILENT thyroiditis is a syndrome which is regarded as a destructive thyroiditis characterized by self-limited thyrotoxicosis sometimes followed by transient hypothyroidism [1, 2], although radioactive iodine uptake is very low, which is a characteristic of subacute thyroiditis. Patients with silent thyroiditis do not have pain or tenderness of the thyroid gland, so the term "painless thyroiditis" is sometimes used instead of silent thyroiditis [3]. Postpartum transient thyrotoxicosis has often been regarded as one of the phenotypes of this clinical entity $[4,5]$.

The etiology of this syndrome has not been confirmed, but from the results of pathological examination of thyroid tissues obtained by needle biopsy during the thyrotoxic phase of silent thyroiditis, which showed prominent lymphocytic

Received: March 7, 1994

Accepted: July 15, 1994

Correspondence to: Dr. Kenji KUSHIMA, 3rd Dept. of Internal Medicine, Showa University School of Medicine, 15-8 Hatanodai, Shinagawa-ku, Tokyo 142, Japan infiltration, this syndrome is regarded as one of the organ specific autoimmune diseases [6]. From the clinical perspective, silent thyroiditis occurs not only in the postpartum period but also in the postoperative period in Cushing's syndrome and after the termination of steroid therapy. This suggests that cancellation of the immuno-suppressive state may be involved in the destruction of thyroid tissues. Thus, a close relationship between silent thyroiditis and the immune system has therefore been suggested $[7,8]$. On the basis of the typing of HLA antigens, Farid et al. [9] reported that silent thyroiditis has an increased frequency of HLA-DR3 and 5, and concluded that it is an autoimmune disease. Tajiri et al. [10] reported an increase in the anti-DNA antibody titer during the thyrotoxic phase of silent thyroiditis, and came to the same conclusion.

In the human immune system, activation of $\mathrm{T}$ cells by antigen-presenting cells is essential in the immune response, and HLA-DR antigens are useful markers of activated T cells [11]. The activated $\mathrm{T}$ cells in various types of autoimmune diseases, 
including Graves' disease, have been measured with monoclonal antibodies to the surface antigens of $T$ cells [14]. A few years later, the percentage of peripheral blood activated $\mathrm{T}$ cell subsets in patients with autoimmune thyroid diseases, measured by two-color dye labelling and dual laser flow cytometry, were reported [15-18]. In the majority of the former reports on thyroid diseases such as Graves' disease and Hashimoto's thyroiditis, the percentages of all activated matured T (HLA-DR $\left.{ }^{+} \mathrm{CD}^{+}\right)$, activated helper/inducer T (HLA-DR $\left.{ }^{+} \mathrm{CD}^{+}\right)$, and activated suppressor/cytotoxic T (HLA-DR ${ }^{+} \mathrm{CD}^{+}$) cells in the peripheral blood were higher than those of healthy volunteers, but the results were conflicting because of differences in methods and subjects. A few cases of silent thyroiditis were reported in these studies $[15,18]$. In order to investigate the involvement of the activation of $T$ cells in the development of silent thyroiditis, we studied activated $\mathrm{T}$ cell subsets in the peripheral blood of patients with silent thyroiditis during both the thyrotoxic and the recovery phases.

\section{Subjects and Methods}

\section{Patients}

The study group comprised three groups, 10 patients with silent thyroidis in the thyrotoxic phase, 12 patient with silent thyroiditis in the recovery phase, and as control, 11 sex-matched and agematched healthy volunteers who has no thyroid or other disease. In our study, all patients were Japanese females. Three of the hyperthyroid patients were postpartum. The mean ages of these three groups were 39.0 (range 20-56), 34.2 (range 17-51), and 30.2 (range 17-57), respectively.

\section{Methods}

1) Two-color dye labelling and dual laser flow cytometry

A five $\mathrm{m} l$ sample of peripheral blood was taken before lunch with a heparinized syringe; $100 \mu l$ of samples were put into test tubes. Then $20 \mu l$ of PE (phycoerythrin) and/or FITC (fluorescein isothiocyanate) labeled antibody were added to the tubes, mixed, and allowed to react at $4^{\circ} \mathrm{C}$ for $30 \mathrm{~min}$. The erythrocytes were hemolyzed with a lysing solution and centrifuged at $4^{\circ} \mathrm{C}$ and $3,000 \mathrm{rpm}$ for
5 min. After discarding the supernatant, PBS was mixed with the residue and centrifuged at $4^{\circ} \mathrm{C}$ and $3,000 \mathrm{rpm}$ for $5 \mathrm{~min}$. The supernatant was then discarded. The positive cell rates of FITC (green) and $\mathrm{PE}$ (red) in washed mononuclear cells were determined by flow cytometer (JASCO, FCM-I.D.).

The percentages of $\mathrm{CD}^{+}, \mathrm{CD}^{+}$, and $\mathrm{CD}^{+}$cells were calculated from the results of the above mentioned analysis. For example; $\left(\mathrm{CD}^{+}\right)=\left(\mathrm{HLA}^{-}\right.$ $\left.\mathrm{DR}^{+} \mathrm{CD}^{+}\right)+\left(\right.$HLA-DR-CD3 $\left.{ }^{+}\right)$

2) Monoclonal antibodies

Commercially available monoclonal antibodies (Becton Dickinson Co., Ltd.) were used in this study. PE labeled anti-HLA-DR antibody (activated cells), FITC labeled anti-CD3 antibody (all matured T cells), anti-CD4 antibody (helper/inducer $\mathrm{T}$ cells) and anti-CD8 antibody (suppressor/ cytotoxic T cells) were used.

3) Measurement of thyroid function

Peripheral blood thyroid hormone levels were measured by RIA. Serum free T3 and free T4 levels were measured with the Amerexs $M$ kits (Amersham Co., Ltd.). Serum TSH levels were measured by a fluoroimmunoassay (FIA) method with a highly sensitive delfia TSH kit (Pharmacia Ltd.).

\section{4) Statistics}

The data are expressed as the mean \pm SD and were analyzed by Student's $t$-test.

\section{Results}

The total $\mathrm{T}\left(\mathrm{CD}^{+}\right)$cell rates in the peripheral blood (PB) mononuclear cells were $70.8 \pm 3.2 \%$ (mean \pm SD), range 63.9 to $76.0 \%$ in the patients with silent thyroiditis in the thyrotoxic phase (STTo), $67.9 \pm 8.7 \%$, range 52.2 to $79.3 \%$ in the patients with silent thyroiditis in the recovery phase (ST$\mathrm{Re})$, and $75.1 \pm 7.0 \%$, range 62.5 to $87.4 \%$ in the healthy control group $(C)$. There were no statistically significant differences among these three groups. In the ST-To group the percentage of $\mathrm{CD}^{+}$ cells of 3 postpartum patients were not so different from the other patients (Fig. 1, left). The helper/inducer $\mathrm{T}\left(\mathrm{CD}^{+}\right)$cell rates in the $\mathrm{PB}$ mononuclear cells were $42.6 \pm 7.3 \%$, range 31.8 to $50.0 \%$ in ST-To, $39.3 \pm 7.6 \%$, range 29.3 to $51.9 \%$ in ST-Re, and $43.9 \pm 6.4 \%$ range 34.1 to $52.1 \%$ in C. There were no statistically significant differences among these three groups. In the ST-To group the per- 
centages of $\mathrm{CD}^{+}$cells of 3 postpartum patients were generally lower than those of the other patients (Fig. 1, center). The suppressor/cytotoxic T $\left(\mathrm{CD}^{+}\right)$cell rates in PB mononuclear cells were 29.6 $\pm 7.5 \%$, range 18.9 to $44.0 \%$ in ST-To, $27.3 \pm 7.1 \%$, range 15.7 to $41.9 \%$ in ST-Re, and $28.8 \pm 5.6 \%$, range 22.2 to $40.0 \%$ in C. There were no statistically significant differences among these three groups. In the ST-To group the percentage of $\mathrm{CD}^{+}$cells of 3 postpartum patients were generally higher than those of the other patients (Fig. 1, right).

The activated $\mathrm{T}\left(\mathrm{HLA}-\mathrm{DR}^{+} \mathrm{CD}^{+}\right)$cell rates in the $\mathrm{PB}$ mononuclear cells were $6.8 \pm 3.0 \%$, range 3.0 to $14.0 \%$ in ST-To $4.6 \pm 2.1 \%$, range 1.9 to $9.0 \%$ in ST$\mathrm{Re}$, and $2.4 \pm 0.6 \%$, range 1.3 to $3.4 \%$ in C. The cell rates in ST-To and ST-Re were significantly higher than in $C$. In the ST-To group the percentage of $\mathrm{HLA}^{-\mathrm{DR}^{+} \mathrm{CD} 3}{ }^{+}$cells of 3 postpartum patients were generally higher than those of the other patients (Fig. 2, left). The activated helper/inducer T (HLA-
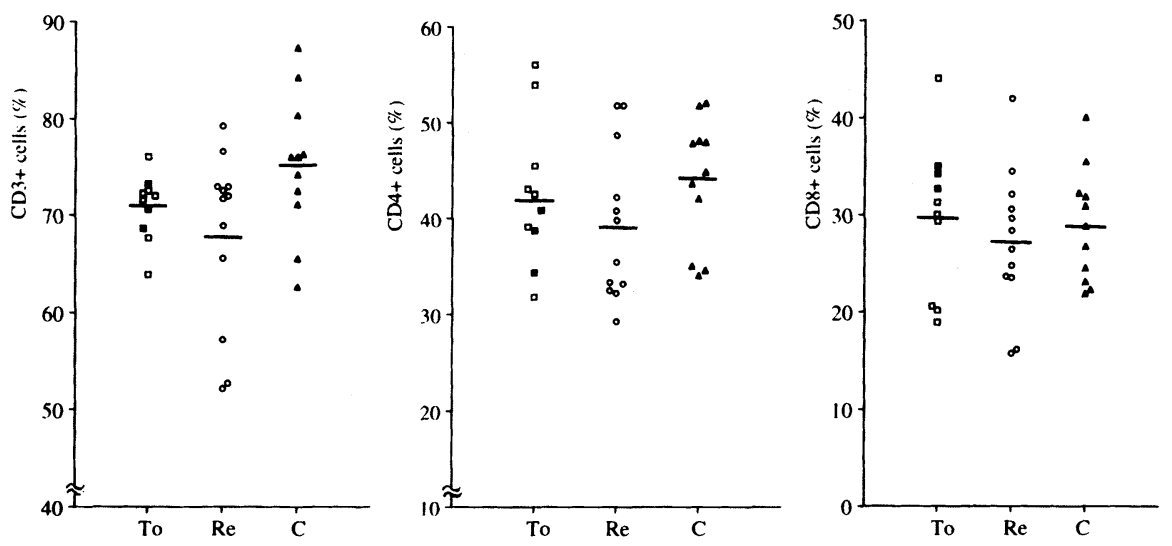

Fig. 1. Percentage of peripheral blood $\mathrm{T}\left(\mathrm{CD}^{+}\right)$cells (left), helper/inducer $\mathrm{T}\left(\mathrm{CD}^{+}\right)$ cells (center) and suppressor/cytotoxic $\mathrm{T}\left(\mathrm{CD}^{+}\right)$cells (right) in patients with silent thyroiditis in the thyrotoxic phase (To), in the recovery phase (Re), and healthy controls $(C)$. In thyrotoxic silent thyroiditis patients, $\mathbf{\square}$, postpartum; $\square$, unrelated to pregnancy.
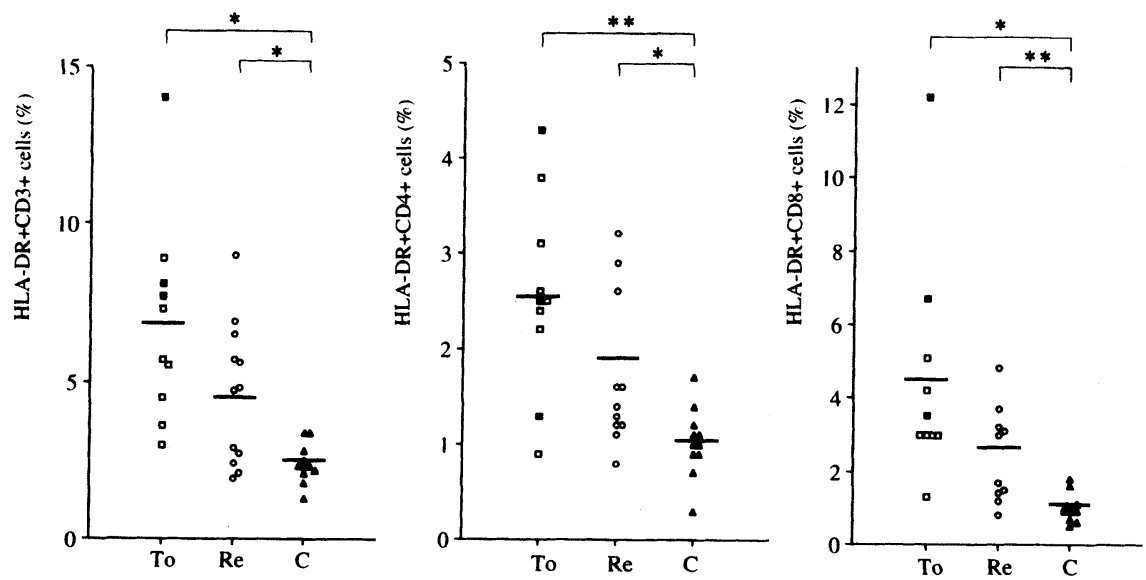

Fig. 2. Percentage of peripheral blood activated $T\left(H L A-D R+C D 3^{+}\right)$cells (left), activated helper/inducer T $\left(\mathrm{HLA}-\mathrm{DR}{ }^{+} \mathrm{CD} 4^{+}\right)$cells (center) and activated suppressor/cytotoxic T (HLA-DR $\left.{ }^{+} \mathrm{CD} 8^{+}\right)$cells (right) in patients with silent thyroiditis in the thyrotoxic phase (To), in the recovery phase (Re), and healthy controls $(C) .{ }^{*} P<0.01 ;{ }^{* *} P<0.001$ (vs. healthy controls; Student's $t$-test). In

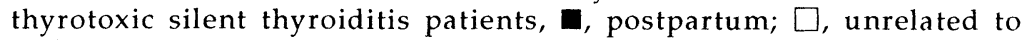
pregnancy. 
$\mathrm{DR}^{+} \mathrm{CD}^{+}$) cell rates in the $\mathrm{PB}$ mononuclear cells were $2.6 \pm 1.0 \%$, range 0.9 to $3.2 \%$ in ST-To, $1.8 \pm$ $0.8 \%$, range 0.8 to $3.2 \%$ in ST-Re and $1.0 \pm 0.3 \%$, range 0.3 to $1.7 \%$ in C. The cell rates in ST-To and ST-Re were significantly higher than in $C$. In the ST-To group the percentage of $\mathrm{HLA}-\mathrm{DR}+\mathrm{CD} 4^{+}$cells of 3 postpartum patients were not so different from the other patients (Fig. 2, center). The activated suppressor/cytotoxic T (HLA-DR $\left.{ }^{+} \mathrm{CD}^{+}\right)$cell rates in the $\mathrm{PB}$ mononuclear cells were $4.5 \pm 2.9 \%$, range 1.3 to $12.2 \%$ in ST-To, $2.6 \pm 1.2 \%$, range 0.8 to $4.8 \%$ in ST-Re and $1.0 \pm 0.4 \%$, range 0.5 to $1.8 \%$ in C. The cell rates in ST-To and ST-Re were significantly higher than in C. In the ST-To group the percentage of $\mathrm{HLA}-\mathrm{DR}{ }^{+} \mathrm{CD} 8{ }^{+}$cells in 3 postpartum patients were generally higher than those of the other patients (Fig. 2, right). The mean \pm SD levels of serum FT3 were $10.1 \pm 5.2 \mathrm{pg} / \mathrm{ml}$ in ST-To, $3.8 \pm$ $0.5 \mathrm{pg} / \mathrm{ml}$ in ST-Re and $3.8 \pm 0.6 \mathrm{pg} / \mathrm{ml}$ in C. The mean \pm SD levels of serum FT4 were $4.6 \pm 2.8 \mathrm{ng} / \mathrm{d} l$ in ST-To, $1.3 \pm 0.2 \mathrm{ng} / \mathrm{d} l \mathrm{in}$ ST-Re and $1.5 \pm 0.2 \mathrm{ng} /$ $\mathrm{d} l$ in $C$. The serum thyroid hormone levels in STTo were significantly higher than in ST-Re and in C.

In the 6 silent thyroiditis patients in the thyrotoxic phase, cell surface antigens were repeatedly analyzed after the normalization of thyroid functions, and values in the thyrotoxic phase of silent thyroiditis and the recovery phase were compared. The activated $\mathrm{T}\left(\mathrm{HLA}-\mathrm{DR}^{+} \mathrm{CD}^{+}\right)$cell rates were increased in one case but decreased in 5 cases. The activated helper/inducer $\mathrm{T}\left(\mathrm{HLA}-\mathrm{DR}{ }^{+} \mathrm{CD} 4^{+}\right)$cell rates were decreased in all 6 cases, being significantly higher in the thyrotoxic phase than in the recovery phase. The activated suppressor/cytotoxic $\mathrm{T}\left(\mathrm{HLA}-\mathrm{DR}{ }^{+} \mathrm{CD} 8^{+}\right)$cell rates were increased in 2 cases but decreased in 4 cases (Fig. 3). During the clinical course, antithyroglobulin antibodies were increased in one case but remained negative in 5 cases. Antithyroid microsomal antibodies were increased in 2 cases but remained negative in 4 cases (data not shown).

\section{Discussion}

In the early 1980s, $\mathrm{T}$ cell subsets in patients with autoimmune thyroid disease were analyzed by many investigators to study the involvement of cell-mediated immunity. Their data were conflicting, but it was generally believed that percentages of circulating $\mathrm{CD}^{+}$and $\mathrm{CD}^{+} \mathrm{T}$ cells in peripheral blood in patients with Graves' disease were similar to those in normal controls $[12,13]$. In contrast, the percentage of circulating $\mathrm{CD}^{+}$cells was lower and that of HLA-DR ${ }^{+}$cells was higher in patients with Graves' disease than those in normal controls [12-14]. Since then, the percentage of activated T cell subsets in patients with autoimmune thyroid diseases has been reported, using two-color dye labeling and dual laser activated cell sorter analysis [15-18]. In the present study, we analyzed
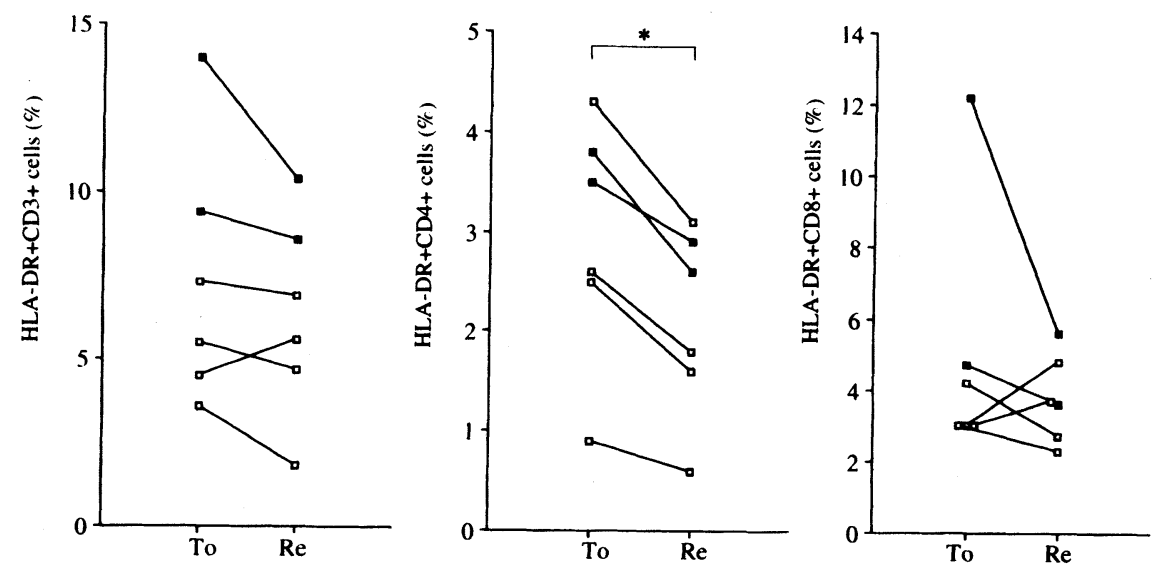

Fig. 3. Percentage of activated $\mathrm{T}\left(\mathrm{HLA}-\mathrm{DR}^{+} \mathrm{CD}^{+}\right)$cells (left), activated helper/inducer $\mathrm{T}\left(\mathrm{HLA}-\mathrm{DR}{ }^{+} \mathrm{CD}^{+}\right.$) cells (center) and activated suppressor/cytotoxic T (HLA$\mathrm{DR}^{+} \mathrm{CD} 8^{+}$) cells (right) in the six patients with silent thyroiditis, in the thyrotoxic phase (To) and in the recovery phase (Re). ${ }^{*} P<0.01$ (Student's paired $t$-test). In silent thyroiditis patients, $\square$, postpartum; $\square$, unrelated to pregnancy. 
circulating peripheral blood (PB) T cells by the twocolor dye labeling method. In our results, activated T cells, HLA-DR ${ }^{+} \mathrm{CD}^{+}$, HLA-DR ${ }^{+} \mathrm{CD}^{+}$, and HLA$\mathrm{DR}^{+} \mathrm{CD} 8^{+}$cells of silent thyroiditis (ST) had higher frequencies of positive staining than those of healthy controls.

Our results indicate that $\mathrm{T}$ cells are activated in ST as in other autoimmune thyroid diseases such as Graves' disease and Hashimoto's thyroiditis. Since ST usually occurs in hashimoto's thyroiditis, and it has been reported that the percentage of circulating activated $T$ cells is increased in Hashimoto's thyroiditis, the findings obtained in our study may indicate the changes in Hashimoto's thyroiditis. To exclude this possibility, we investigated the relation between the phase of ST and activated $\mathrm{T}$ cell subsets, the serum concentrations of thyroid hormones and the percentages of activated T cells in 6 patients with ST in the thyrotoxic phase, in whom cell surface antigens were repeatedly analyzed after the normalization of thyroid functions. The percentage of activated helper/inducer $\mathrm{T}\left(\mathrm{HLA}-\mathrm{DR}{ }^{+} \mathrm{CD} 4{ }^{+}\right)$cells was decreased in the recovery phase in all 6 patients. The activation of $\mathrm{CD}^{+}$cells was therefore related to destruction of the thyroid gland, but the percentage of activated suppressor/cytotoxic T (HLA-DR+CD8 ${ }^{+}$) cells was increased in the recovery phase in 2 out of 4 patients with ST unrelated to pregnancy, but it was decreased in 2 of the postpartum patients. In a previous study by Tötterman et al. [17], after four to six weeks of methimazole therapy for patients with Graves' disease, HLA-DR ${ }^{+} \mathrm{CD}^{+}$cells were increased. Ohashi et al. [18] also observed increased HLA-DR ${ }^{+} \mathrm{CD}^{+}$cells in patients with treated Graves' disease. It is considered that the suppression of autoimmunity might occur with the increase in number of $\mathrm{HLA}-\mathrm{DR}{ }^{+} \mathrm{CD} 8^{+}$cells in patients with Graves' disease and in some cases with ST unrelated to pregnancy. On the other hand, suppression of autoimmunity might occur in a different way in patients with hyperthyroid postpartum thyroiditis and in the other cases with ST unrelated to pregnancy.

To distinguish Graves' disease from destructive thyrotoxicosis, Iwatani et al. [19] reported on the measurement of peripheral blood $\mathrm{CD}^{+} \mathrm{B}$ cells. They reported that the percentage of $\mathrm{CD}^{+} \mathrm{B}$ cells in patients with Graves' disease was higher than in destructive thyrotoxicosis, and they concluded that the proportion of $\mathrm{CD}^{+} \mathrm{B}$ cells is useful for the diagnosis of Graves' disease and its differentiation from destructive thyrotoxicosis. They also reported that in patients with thyrotoxic Hashimoto's disease, $\mathrm{CD}^{+}, \alpha \beta \mathrm{TCR}^{+} \mathrm{T}, \alpha \beta \mathrm{TCR}^{-} \mathrm{T}$, and $\mathrm{CD}^{+}$ cells were fewer than in the controls. And their number of $\mathrm{CD} 4{ }^{+} \mathrm{CD} 8{ }^{+}$cells, and the $\mathrm{CD} 4 / \mathrm{CD} 8$ cell ratio were higher than in the controls. But in the patients with euthyroid Hashimoto's disease only $\mathrm{CD}^{+}$, and $\alpha \beta \mathrm{TCR}^{+} \mathrm{T}$ cells were fewer than in the controls. And there was no difference between untreated Graves' disease and controls in the number of these cells [20]. From these reports we could imagine that the activation of T cells in ST was different from that in other autoimmune thyroid diseases such as Graves' disease and Hashimoto's thyroiditis.

Another possibility is that thyrotoxicosis may induce these $\mathrm{T}$ cell changes, but Jackson et al. reported that activated $\mathrm{T}$ cell population were normal in non-immunogenic thyrotoxicosis [14]. And in our study, because there was no correlation between activated $T$ cell rates and thyroid hormone levels, we supposed that $T$ cell activation was not induced by thyrotoxicosis.

It is well known that the activation of $\mathrm{T}$ cells might be induced by viral infection. Ohashi et al. [18] reported that PB T cells were activated in patient with subacute thyroiditis (SAT) and returned to normal when they recovered. In our results, PB $\mathrm{T}$ cells in patients with ST remained higher than in healthy controls even when they recovered. We therefore consider that the etiological cause of ST is different from that of SAT.

These results may indicate that $T$ cells are activated in patients with ST, especially in the thyrotoxic phase, and may indicate that ST is a disease of autoimmune origin.

With respect to postpartum thyroiditis, in our results $\mathrm{HLA}-\mathrm{DR}^{+} \mathrm{CD}^{+}$and HLA-DR ${ }^{+} \mathrm{CD} 8^{+}$cells in postpartum hyperthyroid silent thyroiditis patients were generally more numerous than those in the other patients. Chan et al. [15] reported on 4 patients with hyperthyroid postpartum thyroiditis. They reported that the percentage of $\mathrm{PB}$ activated $T$ cells in these patients was higher than in normal controls, and HLA-DR ${ }^{+} \mathrm{CD} 4{ }^{+} / \mathrm{HLA}-\mathrm{DR}{ }^{+} \mathrm{CD}^{+}(\%$ activated T-helper-inducer) cells was lower, and

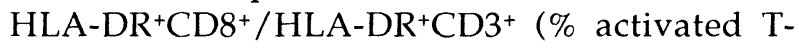
suppressor-cytotoxic) cells was higher than in hypothyroid and euthyroid patients. It is not possible to compare these results directly with ours, so we 
calculated for our 3 postpartum hyperthyroid patients that the mean value for HLA-DR ${ }^{+} \mathrm{CD}^{+} /$ HLA-DR ${ }^{+} \mathrm{CD}^{+}$cells was $31 \%$ (normal control was $44 \%)$, and that of HLA-DR ${ }^{+} \mathrm{CD} 8^{+} / \mathrm{HLA}^{-\mathrm{DR}^{+} \mathrm{CD}^{+}}{ }^{+}$ cells was $72 \%$ (normal control was $43 \%$ ). We studied only three cases, we could not statistically analyzed this result, but we supposed that it was due to the fact that the percentage of HLA-DR+CD3 ${ }^{+}$ and HLA-DR ${ }^{+} \mathrm{CD} 8^{+}$cells in our postpartum pa- tients were higher than those in normal controls, and this result was nearly the same as that of Chan et al. On the other hand, in our study of 6 ST patients, HLA-DR ${ }^{+} \mathrm{CD} 8^{+}$cells had not increased after normalization of thyroid functions. In view of these results we could imagine that postpartum thyroiditis is related to different autoimmune disorders from the ST unrelated to pregnancy. We would like to study this further.

\section{References}

1. Nikolai TF, Brosseau J, Kettrick MA, Roberts R, Beltaos E (1980) Lymphocytic thyroiditis with spontaneously resolving hyperthyroidism (silent thyroiditis). Arch Intern Med 140: 478-482.

2. Smallridge RC, De Keyser FM, Van Herle AJ, Butkus NE, Wartofsky L (1986) Thyroid iodine content and serum thyroglobulin: cues to the natural history of destruction induced thyroiditis. J Clin Endocrinol Metab 62: 1213-1219.

3. Woolf PD, Daley R (1976) Thyrotoxicosis with painless thyroiditis. Am J Med 60: 73-79.

4. Fein HG, Goldman JM, Weintraub BD (1980) Postpartum lymphocytic thyroiditis in American women: a spectrum of thyroid dysfunction. $A m \mathrm{~J}$ Obstet Gynecol 138: 504-510.

5. Amino $N$ (1991) Postpartum thyroid disease. In: Bercu BB, Shulman (eds) Advances in Experimental Medicine and Biology. Plenum Press, New York, vol 299: 167-180.

6. Mizukami $\mathrm{Y}$, Michigishi $\mathrm{T}$, Hashimoto $\mathrm{T}$, Tonami N, Hisada K, Matsubara F, Takazakura E (1988) Silent thyroiditis: a histologic and immunohistochemical study. Hum Pathol 18: 423-431.

7. Maruyama H, Kato M, Mizuno O, Kataoka K, Matsuki S (1982) Transient thyrotoxicosis occurred after cessation of steroid therapy in a patient with autoimmune thyroiditis and rheumatoid arthritis. Endocrinol Japon 29: 583-588.

8. Takasu N, Komiya I, Nagasawa Y, Asawa T, Yamada T (1990) Exacerbation of autoimmune thyroid dysfunction after unilateral adrenalectomy in patients with Cushing's syndrome due to an adrenocortical adenoma. N Engl J Med 322: 17081712.

9. Farid NR, Hawe BS, Walfish PG (1983) Increased frequency of HLA-DR3 and 5 in the syndromes of painless thyroiditis with transient thyrotoxicosis: evidence for an autoimmune aetiology. Clin Endocrinol 19: 699-704.

10. Tajiri J, Higashi K, Morita M, Ohishi S, Umeda T, Sato T (1986) Elevation of anti-DNA antibody titer during thyrotoxic phase of silent thyroiditis. Arch
Intern Med 146: 1623-1624.

11. Winchester RJ, Kunkel HG (1979) The human Ia system. In: Dixon FJ, Kunkel HG (eds) Advances in Immunology. Academic Press, New York, vol 28: 221-292.

12. Sridama V, Pacini F, DeGroot LJ (1982) Decreased suppressor T-lymphocytes in autoimmune thyroid diseases detected by monoclonal antibodies. J Clin Endocrinol Metab 54: 316-319.

13. Ludgate ME, McGregor AM, Weetman AP, Ratanachaiyavong S, Lazarus LH, Hall R, Middleton GW (1984) Analysis of T cell subsets in Graves' disease: alterations associated with carbimazole. $\mathrm{Br}$ Med J 288: 526-530.

14. Jackson RA, Haynes BF, Burch WM, Shimizu K, Bowring MA, Eisenbarth GS (1983) $\mathrm{Ia}^{+} \mathrm{T}$ cells in new onset Graves' disease. I Clin Endocrinol Metab 59: 187-190.

15. Chan JYC, Walfish PG (1986) Activated ( $\left(\mathrm{Ia}^{+}\right)$T-lymphocytes and their subsets in autoimmune thyroid diseases: analysis by dual laser flow microfluorocytometry. J Clin Endocrinol Metab 62: 403-409.

16. Ishikawa N, Eguchi K, Otsubo T, Ueki Y, Fukuda T, Tezuka H, Matsunaga M, Kawabe Y, Shimomura C, Izumi M, Ban Y, Ito K, Nagataki S (1987) Reduction in the suppressor-inducer $\mathrm{T}$ cell subset and increase in the helper $\mathrm{T}$ cell subset in thyroid tissue from patients with Graves' disease. J Clin Endocrinol Metab 65: 17-23.

17. Tötterman TH, Karlsson FA, Bengtsson M, MendelHartvig I (1987) Induction of circulating activated suppressor-like $\mathrm{T}$ cells by methimazole therapy for Graves' disease. N Engl J Med 316: 15-22.

18. Ohashi H, Okugawa T, Itoh M (1991) Circulating activated $\mathrm{T}$ cell subsets in autoimmune thyroid diseases: differences between untreated and treated patients. Acta Endocrinol (Copenh) 125: 502-509.

19. Iwatani $Y$, Amino N, Kaneda T, Ichikawa K, Tamaki H, Tachi H, Matsuzuka F, Fukata S, Kuma K, Miyai $\mathrm{K}$ (1989) Marked increase of $\mathrm{CD}^{+} \mathrm{B}$ cells in hyperthyroid Graves' disease. Clin Exp Immunol 
78: 196-200.

20. Iwatani $Y$, Amio N, Hidaka $Y$, Kaneda $T$, Ichihara K, Tamaki H, Matsuzaka F, Fukata S, Kuma K, Miyai K (1992) Decrease in $\alpha \beta$ T cell receptor nega- tive T cells and CD8 cells, and an increase in $\mathrm{CD} 4{ }^{+} \mathrm{CD} 8{ }^{+}$cells in active Hashimoto's disease and subacute thyroiditis. Clin Exp Immunol 87: 444449 . 